\title{
Igre z mimezisom v poljski in slovenski prozi devetdesetih let
}

\author{
BOŻENA TOKARZ \\ Uniwersytet Ślaski w Katowicach, Instytut Filologii Stowianskiej, \\ Ul. Żytnia 8, PL-41-200 Sosnowiec, btokarz@gmx.net
}

\begin{abstract}
Igre z mimezisom med množico različnih struj in individualnih poetik v poljski in slovenski prozi devetdesetih let določajo model recepcije in strukturo besedil. Naklonjene so prečkanju žanrskih, zvrstnih, kulturnih, predstavitvenih mej, tako da strukturo besedila spreminjajo v polje dialoga, ki bralcu nudi drugačna doživetja kot zaprta fabula.
\end{abstract}

Games with mimesis, present among the numerous trends and individual poetics in Polish and Slovene prose of the '90s, define the model of receiving compositions and the model of their structure. They conduce to crossing borders between genres, cultures, borders in imagination, through making a field of a dialogue in the structure of a text. That field delivers other reading experiences than a closed story.

Ključne besede: mimezis, fikcija, fabula, igre, poljska in slovenska proza devetdesetih let

Key words: mimesis, fiction, story, games, Polish and Slovene prose of the '90s

Mimezis kot estetsko kategorijo opazujemo s širše antropološke in filozofske perspektive, kar se odraža v raznolikih načinih njegovega razumevanja in obsežni strokovni literaturi. V 19. stoletju so ga močno povezovali z realizmom, kar je privedlo do pomenskega izenačenja obeh pojmov, $v$ skladu s tem pa tudi do prizadevanja za ustvarjanje iluzije resničnega bivanja $\mathrm{v}$ predstavljenem svetu. Literarni programi realizma, oprti na filozofsko verovanje $v$ obstoj objektivne resničnosti, so se osredotočili na tehnike vernega predstavljanja, kar je poudarilo objektivnost obstoja pojavov, s tem pa spoznavno(stno) resnico predstavljanih svetov. V literaturi druge polovice 19. stoletja se je realizem izoblikoval kot litararni tok in slog (Głowiński in drugi 1988: 422-423; Mar- 
kiewicz 1991: 816-819; Mitosek 1991: 909-921). Bil je najizrazitejša realizacija mimetičnosti, skupaj s poznejšim naturalizmom, v katerem je mogoče videti najskrajnejšo obliko mimetizma.

Alternativna (literarna) resničnost je bila, skupaj s svojo potencialno manipulativnostjo, zaradi narave jezikovnih upodabljajočih sredstev čedalje odločneje postavljana pod vprašaj - kot lažna podoba, literarna sredstva ekspresije pa so začela vstopati v javno življenje. 20. stoletje je sprva podvomilo, končno pa zavrglo tezo o literarni fikciji kot iluziji, prevari, ki na osnovi lastnih domišljijskih predstav povzroča lažni občutek prisotnosti stvari. Vprašanja o mimezisu in realizmu, ki so se pojavila v 20. stoletju, zrcalijo večno ontološko protislovnost literature; protislovnost, ki spada med distinktivne značilnosti tudi drugih vej umetnosti. Literatura z lastnimi jezikovnimi in kompozicijskimi sredstvi gradi avtonomno resničnost, alternativno zunanji resničnosti. Istočasno je v manjši ali večji meri prepuščena različnim družbenim nalogam. Njena služnostna funkcija je povezana $\mathrm{z}$ dejstvom, da sodeluje $\mathrm{v}$ komunikacijskem procesu, v katerem vstopa $\mathrm{v}$ interakcijo $\mathrm{z}$ drugimi oblikami kulture, npr. $\mathrm{z}$ drugimi umetnostmi, znanostjo, s politiko in z vsakdanjim življenjem. Z njimi jo povezuje izpolnjevanje komunikacijskih funkcij: estetske, spoznavne in vzgojne. Na specifičnost, drugačnost vsakega posameznega literarnega kaže in jo poudarja vsakokratna samosvojost v izbiri gradbenih elementov in načinov uporabe jezika. Ker literatura živi v simbolnem prostoru, prejemnika v enaki stopnji zasužnjuje (s tem, da ga vleče v predstavljeni svet) kot osvobaja.

Literatura tako presega meje resničnosti; ko se poslužuje tako neracionalne oblike spoznavanja, kot je intuicija, pogosto vstopa v svet magije in metafizičnih vrednot. Vedno pa obstaja določena stopnja homologije med umetnostno strukturo dela in strukturo resničnosti (v kateri delo obstaja): vizualno, mentalno, intelektualno ipd. Način vključitve človeka v sodobni svet, sprejemanje ali zavračanje le-tega določa mimetičnost, ki je nekje v razponu »med pretvarjanjem in referenčnostjo«, kot piše Zofia Mitosek (2002: 25-46). Ponovno utelešenje realističnega mimezisa ni mogoče, saj se ni spremenil samo svet (zaradi konkretnih človekovih dejanj), ampak je danes drugačen tudi način njegovega prebiranja (prim. Eco 1999), ki je vedno odvisen od časa in znanja.

S posnemanjem, mimezisom že Aristotel ni mislil na trpno kopiranje sveta, saj naj bi bilo preslikovanje povezano z igranjem resničnosti $\mathrm{v}$ umetnosti, tj. predstavljanjem (Słownik terminów literackich: 284-285; prim. Arystoteles 1989). Posnemanje in igranje resničnosti se izvaja v okvirih predstavljenega sveta, ki ga vsebuje fabula literarnega dela. Predstavna/predstavljajoča funkcija fabule lahko služi posnemanju resničnosti ali pa gradnji fantazijskih svetov, pri tem pa imajo tako prve kot druge alternativen značaj, tj. motivacijsko izvirajo iz notranje resničnosti.

Mimezis določajo aktualna ikonosfera in trenutna komunikacijska orodja; oboje vpliva na opazovalni efekt in izkoristek spomina. Svet, katerega alternativa je literatura, funkcionira skladno s splošno spoštovanimi normami, brez možnosti pogajanja. Pogajalski značaj literature izvira iz dialoga, celo polemike s podobo resničnosti, ki jo slika avtor, saj je umetnikova naloga videti več in 
bolje kot ostali - kot je pisal Marshall McLuhan: »Umetniku pripada [...] v družbi vloga navigatorja, ki pravilno bere kompas in določa kurz [...] Je [...] svetovalec tako v sferi delovanja kot v sferi razmišljanja. [...] naloga umetnosti je omogočiti percepcijo otopelim ljudem, katerih sposobnosti opažanja je zavrla okolica, ki jih ne opazi« (prim. McLuhan 1975: 304, 307; prevod iz poljščine); pa tudi videti predmet skupaj z njegovo strukturo in njenim vzrokom - kot je slikovito prepričeval Roland Barthes v zapisu o Charlieju Chaplinu, ki da »[...] kaže publiki svojo slepoto na tak način, da bi (publika) hkrati videla slepca in predstavo slepca. Videti, kako nekdo ne vidi, je najboljša pot proti jasnemu opažanju tistega, česar sam junak ne dojame [...]« (Barthes 1970: 63; prevod iz poljščine).

Od časa, ko sta oba raziskovalca podala citirani izjavi - šestdesetih let prejšnjega stoletja - se je na področju samozavedanja umetnikov veliko spremenilo, a so se komunikacijski procesi razvili v smer, ki sta jo opazila. Čeprav so sicer umetniki čedalje pogosteje izgubljali vero v idejo, da igrajo pomembno vlogo v potrošniški družbi, niso povsem opustili alternativne drže v odnosu do norm, ki veljajo v resničnem življenju.

Literaturi pripisana polemičnost do zunanjega sveta se je v prozi 90. let podvojila v polemičnost do same literature, kar je še vedno povezano z umetniškim samozavedanjem in pisateljevo pozicijo v multimedialni kulturi. Na Poljskem in v Sloveniji so se spremembe dotaknile tako družbenopolitičnih razmer kot tudi kondicije samega pisatelja, ki zdaj ni bil le osvobojen obveze biti vest naroda ali njegov učitelj, ampak se je znašel v medijsko konkurenčnem prostoru. Z možnostmi, ki jih ponuja tehnika, povezani civilizacijski razvoj dvajsetega stoletja je vplival na umetniško, antropološko in komunikacijsko-družbeno zavest pisatelja. Vendar pa se dotlej nikjer v srednji Evropi (razen v kratkem dvajsetletnem obdobju med svetovnima vojnama na Poljskem) politični dogodki niso v istem času in prostoru tako intenzivno srečali s civilizacijsko-kulturnimi: osamosvojitev slovenske države, prekinitev s sovjetsko (rusko) politično-družbeno dominacijo in rekapitalizacija ter demokratizacija na Poljskem na eni strani in kulturni pojavi komunikacijske multimedialnosti na drugi. Poljski in slovenski kritiki so od te situacije pričakovali prelom (prim. Kos 1991). Pričakovane so bile radikalnejše spremembe od teh, ki so se res zgodile, zlasti na Poljskem. Te prognoze kot da niso upoštevale umetniške evolucije proze, ki je jasno razvidna vse od sedemdesetih let, njene simptome pa je bilo mogoče zaznati že veliko let prej. ${ }^{1}$

Alternativno držo v prozi devetdesetih let je mogoče opaziti na ravni relacije z zunanjo resničnostjo in z literaturo kot formo konceptualizacije te resničnosti v obliki dveh tipov umetniških preferenc: obrata v smer magije in materialistične metafizike ter obrata $v$ smer metafikcije. Iz magičnega realizma pisatelji

${ }^{1}$ Prim. mdr. Stala 2000: 1; Czapliński 1997 - v pogovoru Przeboleć przełom. Rozmowa z historykiem literatury i krytykiem - Przemysławem Czaplińskim (»Pro Arte« 1998, zv. 4) je končal spor o vlogi iz leta 1989 in to obdobje v razvoju proze imenoval »neprelomen prelom« (»przełom nieprzełomowy«). 
devetdesetih let izbirajo relativizem dveh svetov - notranjega in zunanjega - ter fabularni mimetizem. Opiraje se nanju, usmerjajo svojo pozornost proti literarnim mehanizmom, ki so zaradi tega, ker so nosilci pomenov in smislov, tudi sami pomenski elementi. Multimedialna in večjezična kultura je namreč sprožila razmišljanje o celoti kot o fragmentu in o fragmentu kot o celoti; po tem ne more nič več motivirati obstoja meja: med tem, kar je mentalno, in tistim, kar je fizično, med orodjem in izdelkom.

Igra, magija in metafikcija so odgovor na aktualni čas: na potrebo po novem pogledu na resničnost (avantgardna gibanja); na ogroženost, ki jo prinašata človek in tehnika, ki jo slednji ustvarja; na razbitje identitete, ki zahteva stalno lepljenje; na čedalje večjo etično prožnost; na pomanjkanje spoštljivosti do drugačnosti; na potrebo po prijetnosti, igri, zabavi, ki aktivira posameznika. Nezaupanje v možnost predstavljanja in poimenovanja fenomena človeškega bitja, stvari, sveta in odnosov človeka z njimi izvira iz zavedanja, da so meje med njimi gibljive. Ambivalentni odnos do literarnega mimezisa je korak v smeri »obzorja pričakovanj« - kot bi to označil Husserl (prim. Święcicka 1993), Eco pa imenoval »sistem prejemnikovih pričakovanj« (prim. Eco 1972: 94; prevod iz poljščine). Tako »obzorje« kot »sistem《 sta rezultat skupinske in posameznikove izkušnje, tj. prebiranja od magičnega realizma je v bistvu njegovo ponovno postavljanje s strani ustvarjalnega subjekta, torej ne preprosta reprezentanca, ampak predstavljanje, ki se dogaja skladno s pričakovanji modelnega bralca (prim. Eco 1993: 72-96; prevod iz poljščine): kritičnega, a čustveno doživljajočega resničnost in distanciranega, zavedajočega se mehanizmov, ki vladajo svetu in literaturi. Prvi pričakuje fikcijsko iluzijo, ker - kot piše Federman - pomeni »ustvarjati iluzijo [...] zavračati resničnost, predvsem prepričanje, da je resničnost resnica« (Federman 1984: 424; prevod iz poljščine). Drugi bi voljno vstopil v interakcijo z oddajnikom, torej od fiktivnega sveta, ki ga je slednji ustvaril, pričakuje povabilo k igri - igra pa je tudi predstavljanjsko upodabljanje resničnosti.

Igra s fabulami je tudi igra s fikcijo, saj spada fabula poleg naracije, junaka, dogodka, časa in prostora med elementarna orodja za ustvarjanje fikcije, pri tem pa jo je treba opazovati tudi kot spoznavni način. To pomeni, da sta fabula in fabularizacija kot mentalni shemi izraz identitete in njene funkcije - svetovnega nazora. Posebna vloga $\mathrm{v}$ fabularizaciji pripada naraciji in akciji: dejavnikoma, ki usmerjata branje, postavljata literarno delo v določen komunikacijski model. Fabula je identična $\mathrm{z}$ akcijo samo v pripovedih in nekaterih realistično-naturalističnih romanih, oprtih na vzročno-posledični determinizem. Njuna sinonimnost je zamajana že v romanih z več zgodbami, ki niso povezane v hierarhični red, ampak so vzporedne ali enakovredne. Akcija (kot element literarnega besedila) obsega dejansko zaporedje dogodkov in oseb v določenem času in prostoru ter pripovedovalčevo perspektivo, s premori in prostorsko-časovnimi premestitvami ter komentarji vred. Fabula pa je mentalni konstrukt, ki nastane na podlagi akcije - torej jo v svet fikcije postavljata oddajnik in prejemnik; vsako besedilo namreč vsebuje svojega modelnega bralca, adresata; slednji se aktualizira v neskončnem številu empiričnih bralcev, ki 
v manjši ali večji meri vstopajo v igro z besedilom. Odločitev v odnosu do polnega obsega fabule je v veliki meri odvisna tudi od bralčeve intertekstne kompetence, čeprav sicer interpretacijsko hipotezo najde v besedilu.

Vlogo igre, ki predstavlja enega aspektov fikcije, poudarjajo raziskovalci, ki sicer zastopajo različne metodološke opcije, kot npr. Umberto Eco, ko analizira repertoar prijemov v okviru notranjih interakcij, ali Kendall Walton, ko predstavlja fikcijo kot »igro pretvarjanja«.

Igra $\mathrm{z}$ besedilom, ki se jo igrata oddajnik in prejemnik, je lahko razvidna v različnih merah. Njen pomen je tako velik, da Kendall Walton »igro pretvarjanja (game of make-believe) razglasi za temeljni označevalnik fikcije in nanjo opre svojo teorijo (prim. mdr. Walton 1984). Podobno tudi Eco pojasnjuje - čeprav še vedno izhaja iz semiotičnih postavk - mehanizme oddajnikovega ustvarjanja fikcije v besedilu, ki bralca vlečejo v svojo mrežo. Prejemnika besedilo (fabula, intriga, ekspresija) emocionalno modelira ali pa se prejemnik - če ima veliko bralnih izkušenj in visoko kulturno zavest $-\mathrm{z}$ besedilom igra, tako da predvideva njegov zaključek (prim. Eco 1993: 125-148). Oba raziskovalca se razlikujeta $\mathrm{v}$ tem, da isti pojav pojasnjujeta s pomočjo različnih pojmov. Eco izbira iz analize literarnih del repertoar prijemov, ki prejemnika vlečejo bolj $\mathrm{v}$ interakcijo $\mathrm{z}$ besedilom kot $\mathrm{z}$ oddajnikom, Walton pa s pomočjo oznak, kot so imaginacija, navideznost, igra, predstava izpostavlja perspektivo in s tem v središče pozornosti postavlja imaginacijo ter čustveno razpoloženje; Anna Łebkowska (2001: 230-235) opaža, da sežemo po knjigo, ker se želimo angažirati v svetu, ki ga ustvarja, in skupaj z literarnimi osebami doživljati postaje njihove usode, čeprav vemo, da takšen svet ne obstaja.

Walton pojasnjuje zasvajajočo moč fikcije s scenarijem (kot bi se izrazil Eco) otroške zabave, ki mu je zavezana. Slednja mu predstavlja prototip bralčevega psihičnega sodelovanja $\mathrm{v}$ fikcijskih dogodkih, in sicer pod pogojem, da se zaveda svoje vloge udeleženca oz. 'tistega, ki rešuje križanko'. A v obeh situacijah - vere in distance do predstave - se bralec z besedilom igra »igro pretvarjanja« oz. se igra z besedilom tako, da »izkorišča svoje izkušnje, znanje in način« branja sveta, tj. »horizont pričakovanj«. Fiktivni mimezis, ki izpolnjuje tudi ludično funkcijo, je vpisan v antropološko perspektivo, saj človek v zabavi in igri podvaja svoje življenje. ${ }^{2}$ Tak je tudi značaj otroške zabave.

Sodobni odnos do mimezisa kot estetske kategorije, ki se s pomočjo fabule uresničuje v podobi literarne fikcije, izvira iz aktualnih percepcijskih mehanizmov, znanja/znanosti, odnosa do preteklosti, prihodnosti in spomina, ki so posledica izjemno dramatičnih civilizacijskih procesov (znanstvenih, političnih, družbenih, komunikacijskih) 20. stoletja. Igre z mimezisom, mdr. s pomočjo oblik magičnega realizma in literarne samorefleksije, opozarjajo na vlogo konstrukcijskih elementov proze. Literarni kod se je poistovetil s kontekstom, saj je v obliki vsebovana interpretacija resničnosti.

${ }^{2}$ Prim. Lotman 1978; na to besedilo se sklicuje tudi A. Łebkowska. 
Slovenska in poljska proza 90. let nočeta več posnemati resničnosti, čeprav se ne odrekata njenemu opisovanju (deskripciji). Pisatelji, zavedajoči se specifičnosti literarnega izraza, postavljajo resničnost sveta 'v oklepaj', za t. i. literarno resnico. Hkratnost teh tendenc, torej pravica proze do tvorjenja možnih svetov in istočasno demaskiranje v njih ustvarjanje iluzije, se na posebno izrazit način kaže v prozi Vlada Žabota in Olge Tokarczuk. Žabot vleče bralca v magijo možnih svetov, Tokarczukova pa istočasno izkorišča inspiracijo z magičnim realizmom in izkušnje z metafikcijsko prozo; njena proza se opira na protislovja: na intelektualno distanco in čustveno poistovetenje.

Čeprav je ves čas postavljana v oklepaj, fiktivna verjetnost Žabotovi prozi dovoljuje ustvarjalno izkoriščanje elementov igre pretvarjanja. ${ }^{3}$ Literarne osebe so igralci, ki igrajo različne vloge, zgodbe pa so najpogosteje fizično neverjetne. So produkti fabul, ki jih je ustvaril avtor in so kot takšne argumenti za psihološko poistovetenje. Zato lahko pretvarjanje, ki junaka Sukuba vodi v paranojo, služi tudi samospoznavanju. Če se posameznik sooča z različnimi vlogami, množi svoje življenje, tako kot to za zabavo počne otrok, in se s tem bogati (prim. Lotman 1978). Nenavadne zgodbe predstavljajo konstrukcije, ustvarjene brez potrebe po mimetični predstavitvi resničnosti. Sicer so identifikacijske fabule, a so osvobojene preprostosti emblema. Od bralca, ki ima do njih različen odnos, zahtevajo interpretativni napor. Bralčevi občutki se oblikujejo na širokem področju med podreditvijo fiktivnemu svetu in zavračanjem njegovih podob. Cilj je samoopredelitev. Žabot provocira. Ko plete svoj roman, skrbi za to, da bi se bralec znašel znotraj sveta, ki (mu) ga je ustvaril; pripoved neprestano prekinja, saj v resnici v njej ni dogodkov, ki bi bili predstavljeni v vzročnoposledičnem zaporedju, cela pripoved pa je zabrisana.

Vedno pa pripovedovalec izhaja iz fizičnega prostora in se osredotoča nanj. Sprva realistični opis ali pripoved o običajnih dogodkih se preoblikuje v verigo spletov situacij in izgledov, ki jih ni mogoče enostavno pojasniti. To namreč ni prostor, ki bi kazal na svoj neposredni designat. Ta prostor je projekcija psihičnega stanja, ki ga popolnoma obvladuje libido. Podrobnost dobi v njej gargantuistični značaj, v katerem pa ni več karnevalskega optimizma (prim. Bachtin 1975). Namesto slednjega dominira mračnost prvotnega elementa. ${ }^{4}$ Žabota namreč zanima neuzaveščena identiteta posameznika, ki sebe in svet doživlja in spoznava iz magične perspektive. Zato čutnost in animistična doživetja dominirajo nad intelektom, s pomočjo katerega ni mogoče prodreti do pomena skrivnosti, saj je razum odgovoren za podobo t. i. objektivne resničnosti, slednja pa se izkaže za igro zornih kotov. Smisel ostaja v ozadju.

Osnovno sredstvo je jezik in v njem konceptualizirana domišljija, intuicija, intelekt, čustva in doživetja. Odtod izvira mdr. Žabotov odnos do fikcije. Čeprav je literarna fikcija pogosto zaznamovana z vprašajem, o njenem obstoju pisatelj

${ }^{3}$ Prim. Walton 1984; termin izhaja od navedenega avtorja.

${ }^{4}$ Prim. Jung 1981. Koncept posamezno in kulturno motivirane podzavesti izvira iz Freudove psihoanalize, iz kategorije $i d$. Prav tako iz Freudove psihoanalize prihaja Žabotovo prepričanje o organizacijski moči libida. 
ne dvomi. Po njeni zaslugi se bralec prepusti prilaščanju, se pusti ugrabiti - kot piše Kendall Walton - in pri tem ostane v položaju ambivalentne odvisnosti od nje: prepustitve in distance.

Posameznikova izkušnja je v tej prozi takó to, za kar se zdi, da je že biló in na kar bi bilo najbolje pozabiti, kot tudi tisto, kar tiči globoko v podzavesti; je mračno in čeprav privlači, hkrati poraja upanje, da se nikoli ne bo zgodilo. Odtod izvira prenikanje literarnih oseb in svetov v romanih Stari pil, Pastorala in Volčje noči, podobno kot se je to dogajalo že tudi v pisateljevi debitantski pripovedni zbirki Bukovska mati, ki je napovedala značaj njegove ustvarjalnosti.

V noveli Vlada Žabota Skrivnost grajske kapelice se gradi dvojna sanjska resničnost. Sanjane podobe s fresk v grajski kapelici odpirajo eksistencialno prvotnost oseb, ki kasneje postanejo junaki drugih, iz prvih izvirajočih sanj. Zarino prebujenje pomeni prehod v globlji sen. Ista grajska kapelica, ki je prisotna tudi $\mathrm{v}$ njem, vznemirja, še bolj pa preseneča $\mathrm{z}$ osebami na freskah. So primitivne, razmazane, daleč od molitvenega zamaknjenja in gotsko-renesančnega vzorca. Njihova čutnost je zajeta v barvi, ne obliki, saj se je slednja utelesila v dogodkih sanjane resničnosti. Opis fizičnega prostora je preoblikovanje sna (fikcije) v drugo sanjano resničnost, z voznikom in vozom, ki spominja na mrliški voz, gozdom, zidom, podobnim pokopališkemu obzidju, graščino s kapelo. Čedalje globlje vstopanje v podzavest, ki jo obvladujeta čutnost erotike in smrti, se dogaja v simbolnem prostoru, njegovi designati pa s svojo večpomenskostjo ustvarjajo utvaro.

Pešpot Fiale Kalmana ima izrazito realističen okvir potovanja. Junak je bil vržen v magičen, tesnobo vzbujajoč, zlovešč in svojevrsten prostor. Določajo ga stene gostišča, v katerem bo prišlo do ritualnega spolnega akta, ki naj bi stari, zaprti družbi pomenila nadomestek življenja. Notranjost gostišča je nasičena z ritualno potencialnostjo. Notranja napetost predstavlja opozicijo brezizhodnemu zunanjemu svetu, ki izginja v megli, plohi in šumenju vode in v kateri vlada neskončna ter večno ponavljajoča se smrt. Fizična osnova Bukovske matere sta prostora gozda in hiše.

Literarne osebe Žabotovih novel ne prestopajo meja prostora, v katerih dominirata metafora in magija (v Bukovski materi - sprememba ženske iz matere v pocestnico, ljubimko, nevesto; v Pešpoti Fiale Kalmana - Lucije v Lučko, odrasle ženske v dekle, erotike v smrt; v Skrivnosti grajske kapelice pa - telesnosti v sanje čedalje bolj oslabelega telesa). V svetu, ki ga ustvarja pripovedovalec, kljub mešanju realnega z nerealnim ni univerzalne simpatije. Nasprotja ostajajo v protislovnem razmerju, ki v telesnem krču, ki ga enkrat povzoča erotična ekstaza, drugič pa smrt, vzbuja strah. ${ }^{5}$ Skrivnost tega prostora in vzrok njegovega pojava je mogoče pojasniti psihoanalitično: s stanji ekstaze prostora, z občutkom izgubljenosti in nekrivdno krivdo ali pa s hrepenenjem po varnem zavetju toplote telesa. Vedno pa je predstavljeni svet prostor eksistencialnega strahu (prim. Žabot 1986).

${ }^{5}$ Prim. Eco 1999 - na temo simpatije. 
Doživljanje celega sveta je namreč zvedeno na telesno čutnost, na freudovski libido. Pri Žabotu torej ni več možnosti za izravnavo oz. pogreznjenje človeka v stvar, saj prevzame pri njem celo mrtvo telo lastnosti erotičnega telesa, ne pa stvari; mrtvi se ponovno rojevajo v različnih osebah. Kljub zakonitostim razkroja predstavlja to telo nedvoumen konkretni element, neke vrste univerzalni gen, ki jamči za obstoj sveta.

V svetu skrivnostnih sil in življenjske potencialnosti vladata - tudi v svetu, predstavljenem v Nimfi in Sukubu - strah in napetost. Če želi preživeti, mora subjekt sprejeti konfrontacijo z utvaro in zlom, ki ga obkrožata, pa tudi z mistiko in mitičnostjo življenja. Vzrok paranoje so prav sile, ki se jih posameznik ne zaveda, a upravljajo z njim. Preganjavice, zlasti tiste z erotično podlago, ki so sicer najpogosteje skrivane, povzročajo pogrezanje junaka Sukuba Valenta Kosmine v prepad. Njegov svet je niz skrajnih sprememb, podobno kot svet junakov drugih Žabotovih romanov. $\mathrm{V}$ tem svetu strah nikoli ne izgine, posameznik pa se mora do njega nekako opredeliti.

Nenepomembno, inspirativno vlogo $\mathrm{v}$ njegovi prozi igrata psihoanaliza S. Freuda (sila libida) in magični realizem. Metaliterarna sila magičnega realizma tiči v njegovi vkoreninjenosti v različne tradicije: evropsko in ameriško. Iz tega sledi, da ga po eni strani spremlja prepričanost v človekovo zvezo z Zemljo in Vesoljem, po drugi pa drža, ki se je oblikovala skozi kritiko razuma, evropsko metabesedilno tradicijo in, končno, literarno ter kulturno izkušnjo, oprto na Jungovo psihoanalizo. Ta lastnost pojasnjuje razliko med evropsko različico magičnega realizma in njegovo iberoameriško mutacijo kot pravega literarnega toka (ki je v drugi polovici 20. stoletja začel svoj povratek v Evropo - prevodi) in postmoderno remutacijo; odgovarja na dvome z izteka prejšnjega stoletja. Ena temeljnih razlik je $\mathrm{v}$ tem, da $\mathrm{v}$ iberoameriški prozi dominirata magična konkretnost in magija, zrasla iz metisaža in ameriške hibridnosti.

Olga Tokarczuk izraziteje kot Žabot kaže, da zanjo predstavlja tehnika magičnega realizma eno izmed orodij v procesu zastavljanja vprašanj o kompleksnosti in skrivnosti človekovega bivanja v svetu. Medsebojno prenikanje zunanjega in notranjega sveta vzbuja tako nemir kot tudi distanco in nezaupanje do vsega, kar je stalno in se zdi zanesljivo. Pripoveduje torej zgodbe, neverjetne v vsej svoji verjetnosti. Ustvarja fabule, ujete v okvire psihološke verjetnosti, kot so Zadnje zgodbe (Ostatnie historie), mitične, kot Anna in v grobnicah sveta (Anna In w grobowcach świata), prostore naravne magije v romanih Pravek in drugi časi (Prawiek i inne czasi) ali Poli/Pola (Bieguni). Njihova interpretacija, tako kot svetovi, ustvarjeni v njih, se dogaja na polju med željo po zatopitvi v verjetje in nezmožnostjo razglašanja resnice: vse je namreč hkrati mogoče in nemogoče. Njena proza je fikcijska in metafikcijska, opušča vero in nevero v ustvarjene možne svetove. Odgovarja na vprašanja literarnega prejemnika, ki, ko sega po knjigi, od slednje pričakuje možnost potopitve v resničnost, drugačno od tiste, v kateri živi. Ob tem se sicer zaveda logične nepravilnosti knjižnih svetov, a vanje vendarle vnaša svoj intelekt in emocije. V literarne svetove hoče verjeti - ne toliko zaradi udobja, ampak predvsem zaradi v njih ustvarjene možnosti odhoda in prekinitve rutine (brez prevzemanja odgovor- 
nosti), konvencije, norme; njegova »vera« torej izhaja iz želje po transgresiji, iz želje po prekoračitvi lastnih meja. Literatura takó ni izključno sprostitev, pobeg, saj prinaša spodbude za samospoznanje, samokreacijo in spoznanje, ob tem pa ponuja tudi veliko prijetnih občutkov, kakršne pričakujemo od zabave. ${ }^{6}$ Prejemnik tako postaja sokreator, čigar sodelovanje zajema ustvarjalne dejavnosti, ki zahtevajo invencijo in sodelovanje v virtualnem prostoru predstavljenega sveta. Tako deluje junakinja pripovedi Olge Tokarczuk Odpri oči, ne živiš več (Otwórz oczy, już nie żyjesz) (prim. Tokarczuk 2001: 7-45).

Junakinja C. ni brez razloga bralka kriminalk. Ta literarna zvrst namreč ne skriva, da se opira na igro s prejemnikom celo v primeru novih zvrstnih različic, ki jih C. imenuje »kriminalke mešanke«. Pripovedovalka predstavlja junakinjo, ko riše njen psihološki portret kot portret osebe, ki v branju takšnega tipa literature išče močna doživetja in s tem nasprotje svoje vsakdanje eksistence - sive uradnice, ki z ničimer ne vzbuja posebne pozornosti. Pripoved rekonstruira bralni akt v perspektivi njegove neomejene interaktivnosti. Junakinjina zaljubljenost v kriminalke $\mathrm{v}$ resnici predstavlja ponovitev sheme uradničinega razumskega dela, le da jo spremlja potreba po presenečenju, ugrabljenosti. Presenečenje in ugrabitev sta tu pasivni drži, prav pasivnost pa jo v življenju najbolj moti, jezi in frustrira.

Če bi bili vsi bralci pasivni in bi se zgolj prepuščali »ugrabitvi« s strani fikcijskega sveta, bi literatura izpolnjevala samo vlogo »zapolnjevalca« notranje praznine in relaksacijsko funkcijo - kot zaustavljalka realnega časa. Ko prejemnik vstopa $\mathrm{v}$ interakcijo z literarnim delom, mu oddaja tudi sebe, svoje ustvarjalne sposobnosti, saj predvideva nadaljnjo usodo likov, se vznemirja zaradi njih, včasih pa jih hoče celo braniti pred nevarnostjo. Želi si posegati v usodo predstavljenega sveta in njegovih likov (prim. Eco 1993: 162-178). Zato C. vstopa $\mathrm{v}$ virtualni svet, predstavljen $\mathrm{v}$ romanu, $\mathrm{v}$ dveh vlogah, in sicer $\mathrm{v}$ vlogi: (1) kreatorja, pri čemer prevzema avtorsko oblast, in (2) agensa, ki ga sam prikliče $\mathrm{z}$ namenom spremembe fabule. V povesti je zanimiv način C.-jinega zagona mehanizma interferenčnih izletov glede brane knjige. Sklicevaje se na (intertekstne) scenarije drugih kriminalnih romanov, ki jih pozna, spreminja fabulo in se izmika dominaciji besedila. Išče nove rešitve avtorskega projekta, noče se več vračati k pripovedovani zgodbi. Izraža svoj upor - kot aktivna in svobodna ustvarjalka pa tudi kot negativna junakinja.

$\mathrm{V}$ pripovedi je bil poudarjen dinamičen značaj literarnega dela, oprt na komunikacijsko interaktivnost, ob tem pa so bile izpostavljene ustvarjalske možnosti, kakršne ustvarja usmeritev kreativne pozornosti (tvorca in prejemnika) na konstrukcijske elemente (npr. fabulo), ki jih aktualizira bralec. Obračanje literarnega komunikata k samemu sebi zajema tudi njegov ontološki status, ki ga fikcija zagotavlja celo v primeru, če jo opremimo z oznako negacije. V svetu fikcije je vse mogoče, vendar razkritje njenih gradbenih načinov suspendira resničnost in verjetnost.

${ }^{6}$ Prim. Walton 1984 - širše na temo literarne igre pretvarjanja. 
Zunanje okvire povesti Odpri oči ... določa pripovedovalec, ko označi njen začetek in konec: nakup knjige in policijski avto pred blokom. Čeprav puščata bralca v izključujočem protislovju med resnico in neresnico ter mu uzaveščata zapeljivost in nevarnost virtualne resničnosti, literarno delo zaradi njiju pridobi navidezno interpretativno kohezijo. To je pripoved o bralni prigodi ženske, ki v knjigi išče novo življenje, pa tudi - o terapevtski funkciji literature. Avtorica postavlja zaskrbljujočo diagnozo resničnosti, ki ni prijetna, saj v njej nastopajoči ljudje iščejo terapijo. Literatura izpolnjuje tudi ta pričakovanja, mnogopomensko odgovarja na prejemnikove potrebe.

Pripovedi, zbrane v prvem delu knjige Igranje na veliko bobenčkov (Gra na wielu bębenkach) so v večji ali manjši meri metafikcijske: Škotski mesec (Szkocki miesiac) se dotika problema dvojne imitacije, kar plastično predstavlja velik dom za lutke; v pripovedi Subjekt (Podmiot) je obravnavano vprašanje identitete subjekta teksta in avtorskega subjekta; Otok (Wyspa) pa je konstrukcija, ki s tem, da v oklepaj postavlja oddajnika in pripovedovalca primarnega besedila, pod vprašaj postavi nujnost in stabilnost literarnega komunikata. V vseh pripovedih je relativizirana mimetičnost literature in njena brezpogojna avtonomija. Razumevanje teh pripovedi je brez upoštevanja obrtniške in ontološke zavesti bralca v interpretacijskem polju omejeno, saj fabule, ki jih narator pripoveduje ali sliši, niso informacije same na sebi, ampak služijo prenašanju bolj zapletenega komunikata, katerega bistvo tiči v skrivnosti človeške psihe, ki omogoča obstoj virtualnih svetov.

Po Tokarczukovi obstaja odvisnost med realno doživeto resničnostjo in virtualnimi svetovi, ki jih v obliki računalniških svetov, literarnih del, umetnosti, magije, sanj in zabave $\mathrm{z}$ nadevanjem mask (dobesednim in $\mathrm{v}$ prenesenem pomenu) ustvarja človeška domišljija. ${ }^{7} \mathrm{~V}$ virtualnem prostoru literature se dogaja srečanje dveh različnih osebnosti, pri tem pa se struktura dela ne spremeni. Zato oddajnik usmerja proti prejemniku signale tako, da bi bil sporazum mogoč v različnih stopnjah. Skrivnost teh prostorov tiči v človeškem razumu, knjiga pa »dokazuje« - kot piše avtorica - »da se vsa resničnost nahaja v človeški psihi« (Tokarczuk 2001: 14). Ta pa kljub temu selektivno - po Eleonor Rosch - zadržuje informacije in podobe resničnosti in gradi subjektivne modele sveta (prim. Cognition and Categorization, 1978; Taylor 2001), tako da obstajajo medsebojno komplementarne slike resničnosti, konceptualizirane v jeziku na vseh njegovih nivojih. Njihovo srečanje se dogaja v prostoru literature, v postopkih predvidevanja, ugotavljanja in razočaranja. Zato se interpreti zgolj približujejo razumevanju polnega smisla literarnega dela, ki ostaja sicer neznano tudi samemu avtorju. Iz takšnega razmišljanja lahko izvira prepričanje, da je svet neskončna pripoved - kot v povesti-bajki Salmana Rushdieja Harun in morje $z g o d b, \mathrm{v}$ kateri je bralčeva pozornost usmerjena na pripovedni način, torej na strukturne elemente, ki so nosilci pomenov in smislov.

${ }^{7}$ Prim. Sartre 1970; domišljijo opisuje kot specifičen, v razumu ustvarjen analogen resničnosti. 
Zanimanje za virtualne svetove literature (in umetnosti nasploh) je razvidno v vsem opusu Tokarczukove: v Potovanju ljudi knjige (Podróż ludzi księgi) so šifrirane v simbolu knjige in življenja knjižnega človeka, tj. oblikovanega skozi znanje, pridobljeno iz knjig in literature (to se ponovi v pripovedi Škotski mesec (Szkocki miesiac)); v Praveku in drugih časih (Prawiek i inne czasy) svet obstaja na meji med magijo prostora in časa ter predstavitvijo realnih dogodkov; v Deus ex ... se pripoved nanaša na srečanje človeške inteligence $\mathrm{z}$ umetno inteligenco računalniških možnih svetov; pa tudi v Zadnjih zgodbah (Ostatnie historie) ostajajo tri sorodnice (mama, babica in vnukinja) v virtualni zvezi - ko vsaka pripoveduje iz lastnega zornega kota, si ureja doživljeni svet skupaj z njegovo »nevidnostjo«, ki je vpisana v to, kar je vidno. Ko se istovetiš (identificiraš) in sodeluješ v virtualnem svetu, ga lahko v vsakem trenutku zapustiš ali izbereš drugo pot; lahko tudi preveriš svoje možnosti, nadarjenost in občutljivost; pred dramatičnostjo nas brani konvencija, ker:

[...] doživete (v tem svetu - op. B. T.) emocije niso radikalne, a v določenem smislu tudi so, ter hkrati niso resnične. Bralec se lahko od besedilnega sveta distancira, saj je njegov gospodar. Razgibana domišljija bere zgodbo v svojem ritmu, sledi podobam. Je aktivna, a se pusti voditi. $V$ romanu srečuje osebe, $v$ katerih vidi predvsem vloge, napisane prav z namenom, da bi se lahko z njimi poistovetila. Tedaj se pojavlja možnost za doživetje očiščujočega strahu, vseh varnih (ker so virtualne) reakcij (Tokarczuk 2001: 14).

Avtorica Igranja na veliko bobenčkov sproža prejemnikovo domišljijo, ko dela svoja besedila v precejšnji meri samorefleksivna. Bralčevo pozornost usmerja na orodja za gradnjo literarne fikcije, ki so nosilci in kažejo na možnosti za aktualiziranje in razširjanje njegovih razumskih in mentalnih izkušenj. Zato se v svojih metafikcijskih pripovedih ne izogiba fabuli in v izrazito fabularna besedila vključuje metafikcijske digresije. Bralec nima vtisa, da se ukvarja $\mathrm{z}$ »motnim morjem pripovedi« celo v neverjetnih zgodbah (npr. Subjekt (Podmiot) ali Otok (Wyspa)), ampak ima nejasen občutek približevanja nekakšni skrivnosti, ki prekoračuje meje čutnih in razumskih izkušenj. Njena metafikcijska proza je odločno fabularna in nemara prav zaradi tega dosega visoko stopnjo bralnega zanimanja s strani oseb z različnimi bralnimi izkušnjami, neodvisno od tega, če v njej prepoznavajo znane sheme ali ne. Sheme so znane tudi iz drugih povesti, a tu - zaznamovane - pomenijo nekaj drugega in na drugačen način spreminjajo kaos $v$ red. ${ }^{8}$

Pisatelji segajo po vzorec proze magičnega realizma z ozirom na ontološki status, ki se v njem pripisuje resničnosti, in zaradi obrtniško-tehničnih razlogov. Objektiven obstoj sveta sicer ni odločno zanikan, vendar ni več pojasnjevan s pomočjo principa identičnosti, odsotnosti nasprotja in principa izključitve tretje možnosti. Za razlago raznolikosti aktualnega sveta ne zadostuje več razumevanje zahodnega racionalizma, t. i. modus ponens, oprtega na vzročno-posledično pojasnjevanje (prim. Eco 1999). Na vsakem področju vseh dejavnosti prisotni

${ }^{8}$ Prim. Czapliński 1997: 109-164; klasifikacije metafikcijskih naracij (fabularne in neepične). 
element spremembe usmerja pozornost ustvarjalcev na skrivnost, neskončnost, dostop, do katerih omogočajo orodja tradicionalne logike, pa tudi njihovo prekoračevanje vse do stopnje zanikanja in razbitja vzročno-posledične verige, ko lahko posledica povratno deluje na lasten vzrok. Magični realizem je ponudil - skupaj z njegovo kritično smerjo - interpretacijo sveta, ki ni nivelirala protislovnosti, potemtakem je bila neredukcionistična.

Virtualnost literarnih svetov, ki so jo pisatelji opazili pred več stoletji, preden so jo razširile računalniške prakse, je literarno mimetičnost postavila pod vprašaj, vse do njenega zanikanja. Kot rezultat procesa razširjanja zavesti o virtualnem obstoju literature pod vplivom prihajajočih družbeno-kulturnih sprememb (z velikim deležem tehnike) je postajala referenčnost literarnega dela čedalje manj vezana na predstavljanje, ujeto v izrazite okvire fikcije (prim. Mitosek 2002: 25-46; Łebkowska 2001).

Fikcija, konkretizirana v fabuli, ima svojo ontološko-logično razsežnost, ki jo izraža način obstoja literature - intencionalnost. Fikcija (ki jo konstituira dejavni besedilni subjekt, ki v jeziku gradi možne, čeprav ne nujno tudi resnične svetove) je nosilec intencionalnosti; odloča o identiteti literarnega dela, slednja pa obstaja glede na kaj zunanjega (avtorja, kulturo, komunikacijske stile, položaj jezika, jezikovno in filozofsko znanje o njem ter okoliščine) in kaj notranjega (koherenco, intenčnost in akceptabilnost). Je pretvarjanje, oprto na številne nivoje verjetnosti, in čeprav verjetnost ni identična resnici, omogoča svobodo domišljije, svobodno projekcijo lastne osebe in bralca ter podoživljanje dogodka in usod posameznih literarnih oseb.

Proza Olge Tokarczuk se razlikuje od proze Vlada Žabota. Njena metafiktivnost ima fabularni značaj, s katerim deluje na bralčeva čustva. Žabotov fabularni svet pa sekundarno spodbuja metabesedilno refleksijo, ki prehiteva doživetje.

$\mathrm{V}$ njuni prozi se fikcija realizira $\mathrm{v}$ fabuli, ki jo pripoveduje pripovedovalec, torej $\mathrm{v}$ epizodah, usodah literarnih oseb in $\mathrm{v}$ dogodkih. Njihova fiktivnost ni niti v stvareh niti v ljudeh, ampak v nemogoči ( $\mathrm{v}$ realnem svetu) verjetnosti tega, kar se dogaja med njimi. »Fikcija torej ne temelji na prikazovanju tega, kar je nevidno, ampak na kazanju, v kakšni stopnji je nevidna nevidnost tega, kar je vidno« (Foucault 1999: 180; prevod iz poljščine). Faucaultovo opažanje se v tem primeru nanaša na pojav, ki ga podobno ali identično ocenjujejo raziskovalci, ki se sicer poslužujejo drugih metodoloških prijemov, npr. McLuhan.

Fikcija relativizira prenikanje pripovedovalčevega zunanjega in notranjega gledišča (V. Žabot) in okvire, ki jih pripovedovalec ustvarja za predstavljanje dogajanja (O. Tokarczuk) in ki dopuščajo različne zorne kote (prim. Npr. O. Tokarczuk: Otok (Wyspa), V. Žabot: Stari pil).

$\mathrm{V}$ antropološko-kulturnem diskurzu literatura z izkoriščanjem možnosti, ki jih skriva fikcija, čedalje pogosteje uzavešča svojo labilno naturo. Pisatelji se čedalje pogosteje poslužujejo igre s fikcijo, da bi sodelovali v kulturnem oblikovanju osebe. Z izkoriščanjem ontološkega statusa literature zaznamujejo svojo lastno subjektivnost in njeno potrebo po voditeljstvu. 
Razumevanje mimezisa se je v 20. stoletju obogatilo zaradi interpretiranja prvotne Aristotelove definicije. Treba se je strinjati z Adornovo sugestijo, da je razumevanje mimezisa odvisno od filozofske drže, tj. sprejetega pogleda na resničnost, in ontološkega statusa, ki mu je pripisan. Za sodobno družbo 20. in 21. stoletja je značilno srečevanje nasprotij: racionalizma znanosti in njeno nemočjo ob mnogih pojavih ter potrebo po skrivnosti; hrepenenja po stalnosti s potrebo po stalni prostosti. Forma magičnega realizma uteleša takšno razumevanje mimezisa in pojasnjuje različne igre s fikcijo in avtonomijo literature.

Igra z mimezisom v prozi O. Tokarczuk in V. Žabota, čeprav v različni obliki in različnih prostorskih okoliščinah, opozarja na znani obvezujoči umetniški imperativ: dvom. Predstavlja tudi odgovor na pojav redukcije in površnosti v zgoščujoči se medijski komunikaciji. »Obstaja možnost redukcije - ne do nedorečenosti (reductio ad absurdum), ampak do svobode « - kot piše o Magrittovem slikarstvu John Berger (1999: 217; prevod iz poljščine). Opozarja tudi na prevratno porušeno $\mathrm{v}$ jeziku izraženo miselno linearnost, saj je slednja zajeta $\mathrm{v}$ tem, kar je skrito za konvencijo, podobo ali njenim opisom (deskripcijo).

\section{VIRI IN LITERATURA}

ARYSTOTELES, 1989: Poetyka. Prevedel in priredil (v poljščini) H. Podbielski. II. izd. Wrocław.

Michail BACHTIN, 1975: Twórczość Franciszka Rabelais. Prev. A. in A. Goreniow. Obdelava, uvod in verifikacija prevoda S. Balbus. Kraków: Wydawnictwo Literackie.

Roland BARTHES, 1970: Mitologie codzienne. Prev. J. Błoński. Idem: Mit i znak. Izbor in spr. beseda J. Błoński. Warszawa: PIW.

John BERGER, 1999: Magritte i niemożliwe. O patrzeniu. Prev. Sławomir Sikora. Warszawa: Fundacja Aletheia.

Cognition and Categorization. Eds. E. Rosch, B. B. Lloyd. Hillsdale: Lawrence Erlbaum, 1978.

Przemysław CZAPLIŃSKI, 1997: Ślady przełomu. O prozie polskiej 1976-1996. Kraków: Wydawnictwo Literackie.

Umberto ECO, 1972: Komunikat estetyczny. Pejzaż semiotyczny. Predgovor M. Czerwiński. Prev. A. Weinsberg. Warszawa.

- -, 1993: Lektor in fabula. Prev. P. Salwa. Warszawa.

- -, 1999: Czytanie świata. Prev. M. Woźniak. Kraków: Znak.

Raymont FEDERMAN, 1984: Surfikcja - cztery propozycje w formie wstępu. Prev. J. Anders. Nowa proza amerykańska. Szkice krytyczne. Izbor, priredba in uvod Z. Lewicki. Warszawa. 
Michel FOUCAULT, 1999: Powiedziane, napisane. Szaleństwo i literatura. Prev. B. Banasiak, T. Komendant, M. Kwietniewska, A. Lewańska, M. P. Markowski, P. Pieniążek. Izbor in priredba T. Komendant. Zaključna beseda M. P. Markowski. Warszawa.

Michał GŁOWIŃSKI, Teresa KOSTKIEWICZOWA, Aleksandra OKOPIEŃ - SŁAWIŃSKA, Janusz SŁAWIŃSKI, 1988: Stownik terminów literackich. I. izd. Wrocław.

Carl Gustaw JUNG, 1981: Archetypy i symbole. Uvod in prev. J. Prokopiuk. Warszawa: Czytelnik.

Janko KOS, 1991: Teze o slovenskem romanu. Literatura, št. 13.

Anna ŁEBKOWSKA, 2001: Między teoriami a fikcją literacka. Kraków.

Jurij LOTMAN, 1978: Lalki w systemie kultury. Prev. P. Ustrzykowski. »Teksty«, št. 6 .

Henryk MARKIEWICZ, 1991: Realizm. Słownik literatury polskiej XIX wieku. Ur. J. Bachórz in A. Kowalczyk. Wrocław.

Zofia MITOSEK, 1991: Realizm. Stownik literatury polskiej XX wieku ... 909-921.

- -, 2002: »Mimesis« - między udawaniem a referencją. Przestrzenie Teorii, št. $1,25-46$.

Marshall McLUHAN, 1975: Wybór pism. Izbor J. Fuksiewicz. Prev. K. Jakubowicz. Uvod K. T. Toeplitz. Wydawnictwa Artystyczne i Filmowe. Warszawa.

Jean-Paul SARTRE, 1970: Wyobrażenie. Prev. P. Beylin. Warszawa: PWN.

Stownik terminów literackich ... 284-285.

Marian STALA, 2000: Coś się skończyło, nic się nie chce zacząć. »Tygodnik Powszechny«, št. 2.

Krystyna ŚWIĘCICKA, 1993: Husserl. Warszawa.

John R. TAYLOR, 2001: Kateogryzacja w języku. Prev. A. Skucińska. Kraków: Universitas.

Olga TOKARCZUK, 2001: Lalka i perła. Kraków.

--, 2001: Otwórz oczy, już nie żyjesz. Idem: Gra na wielu bębenkach. Wałbrzych: Ruta.

Kendall WALTON, 1984: Uznanie fikcji: zawieszenie niewiary czy udawanie wiary. Prev. P. Mróz. Estetyka w świecie. Izbor besedil in redakcija M. Gołaszewska. Kraków: Wydawnictwo Literackie.

Vlado ŽABOT, 1986: Bukovska mati. Ljubljana: Cankarjeva založba. 


\section{GAMES WITH MIMESIS IN POLISH AND SLOVENE PROSE OF THE '90S}

The '90s have been defined as a turning-point without a turn in Poland. Transformations in poetry and prose had a more evolutionary than revolutionary character. However, it is a fact that there was a wave of widely-read débuts in prose (metafictional), reporting, science-fiction, fantasy, prose of every-day life, prose on the border of metaphysics and prose on unpopular themes.

Slovenian critics noticed a clear turning-point in the prose of the '90s, and in literary life as well. The turning-point was marked by a freeing of the artistically aesthetic imagination from the duty of being a guide to the national awareness, that is from its didactic function. Metafiction, urbanism, lyricism, the fantastic, small dialectal homelands, and minorities of different kinds, all attracted attention in prose.

The artistic and thematic diversity of prose has its appeal in both literatures as an artistically aesthetic phenomenon and as an expression of the awareness of the turn of centuries. Games with mimesis, present among numerous trends and individual poetics, define models of receiving compositions and models of their structure. They conduce to crossing borders between genres, cultures, borders in the imagination, and through making a field of dialogue from the structure of a text. That field delivers other reading sensations than a closed story.

The prose of Olga Tokarczuk, Magdalena Tulli, Andrej Blatnik, and Vlado Žabot provides different examples of cognitive and aesthetic attitudes and artistic forms based on awareness, which are created by contact with possible literary worlds. 